\title{
Assessment of wind energy potential for small scale water pumping systems in the north region of Cameroon
}

\author{
Dieudonné Kidmo Kaoga ${ }^{1 *}$, Noël Djongyang ${ }^{1}$, Serges Yamigno Doka ${ }^{2}$, Danwe Raidandi ${ }^{3}$ \\ ${ }^{I}$ Department of Renewable Energy, Higher Institute of The Sahel, University of Maroua, PO Box 46 Maroua, Cameroon \\ ${ }^{2}$ Department of Physics, Higher Teacher's Training College, University of Maroua, PO Box 46 Maroua, Cameroon \\ ${ }^{3}$ Department of Mechanical Engineering, National Advanced Polytechnic School, University of Yaoundé I, PO Box 8390 Yaoundé \\ Cameroon \\ *Corresponding author E-mail: kidmokaoga@gmail.com
}

Copyright $\odot 2014$ Dieudonné Kidmo Kaoga et al. This is an open access article distributed under the Creative Commons Attribution License, which permits unrestricted use, distribution, and reproduction in any medium, provided the original work is properly cited.

\begin{abstract}
Based on the wind data recorded over a six year period (2007 to 2012) as observed in the main meteorological station of the Garoua International airport, an assessment of the wind potential has been performed by means of the Weibull Probability Density Function (PDF) with two parameters. The maximum likelihood estimation method (MLE) was used to estimate the dimensionless Weibull shape parameter $\mathrm{k}$, and the Weibull scale parameter $\mathrm{C}$. The maximum wind power density extracted by the blades as well as the useful average hydraulic power output and the daily water production of the hypothetic windmill were determined in order to forecast applications in the north region of Cameroon such as providing domestic water, watering farm animals and small scale irrigation.
\end{abstract}

Keywords: Hydraulic Power Output, Power Density, Weibull Distribution, Weibull Parameters, Wind Speed.

\section{Introduction}

With fast growing energy demand, in addition to rising environmental consciousness, it has become crucial to enhance energy supply with renewable sources of energy. This is particularly true for wind, an inexhaustible resource which has the potential to lower greenhouse gas emissions and local air pollutants coupled with the burning of fossil fuels.

In the north region of Cameroon, wind can be reasonably harnessed to provide significant quantities of energy to support rural areas' needs such as acquiring clean water, be it for domestic purposes, for livestock or for irrigation. Providing clean water is one of the best ways to improve health and increase the productive capacity of the population. Accessing to clean water is best achieved through pumping from underground water aquifers rather than using surface water sources, which are often polluted [1]. Given a good quality wind site and because of the moderately small quantities of water needed, wind pumping for community water supply and livestock watering could be cost-effective. However, irrigation pumping requires large quantities of water during the dry season. The seasonal variation in the north region of Cameroon is conventionally expressed by two climatic seasons, namely the dry season (mid-October to mid-July) and the rainy season (mid-July to mid-October). The months of July and October are the transition periods between the two seasons. The windiest months are observed between March and June. So far, studies on wind characteristics in the north region of Cameroon are limited.

A certain number of difficulties are related to the wind, as an energy source. One of these difficulties is wind speed variability. As a result, to forecast the energy output of a wind energy conversion system, the Weibull PDF with two parameters, the dimensionless Weibull shape parameter $\mathrm{k}$, and the Weibull scale parameter $\mathrm{C}$, is the model utilized. There are several methods which can be used to estimate the Weibull parameters $C$ and $k$, depending on which wind statistics are available and what level of sophistication in data analysis one wishes to employ[5]. In this study, the MLE method has been chosen as a comprehensive understanding of wind characteristics required to assess the potential wind. Despite the wind categories suitable for the development of mechanical wind power for water pumping, there seems to be limited interests in wind energy as there are limited previous researches in this field. An attempt has been made by Tchinda et al. [2] to evaluate the wind energy potential with meteorological method using wind data from 1990 to 1999. 
The aim of this study is to assess wind energy potential for water pumping windmills in the north region of Cameroon, provided that monthly wind data over a six year period (2007 to 2012) were supplied. It's then proceeded to the estimation of the daily water production of the hypothetic windmill, based on the total dynamic head, ranging from 10 to 30 meters for applications such as household use, small scale irrigation, and livestock.

\section{Methods and materials}

\subsection{Data source}

The data provided for the study are monthly mean wind speeds, recorded over six year period, from 2007 to 2012 at 10 $\mathrm{m}$ height above ground level (AGL). These data were obtained from the main meteorological station located in the Garoua International airport. The table 1 gives the geographical coordinates of the location.

\begin{tabular}{ll}
\multicolumn{2}{c}{ Table 1: Geographical coordinates of the study area } \\
\hline Variable & Value \\
\hline Latitude & $09^{\circ} 20^{\prime} \mathrm{N}$ \\
Longitude & $13^{\circ} 23^{\prime} \mathrm{E}$ \\
Elevation & 242 meters height AGL \\
\hline
\end{tabular}

\subsection{Weibull distribution}

The daily, monthly, seasonal, and yearly wind speed probability density distributions are modeled using the Weibull PDF. The Weibull PDF can be used with acceptable accuracy for prediction of wind energy output required for preliminary design and assessment of wind power plants [3]. The variation in wind speed are most often described by the Weibull PDF with two parameters, the dimensionless Weibull shape parameter $k$, and the Weibull scale parameter $C$ which have reference values in the units of wind speed. The PDF function $f(V)$ is given by the following [4], [20]: $f(V)=(k / C) \cdot(V / C)^{k-1} \cdot \exp \left(-(V / C)^{k}\right)$

Where: $f(V)=$ probability of observing wind speed $V$

$V=$ wind speed $[\mathrm{m} / \mathrm{s}]$

$C=$ Weibull scale parameter $[\mathrm{m} / \mathrm{s}]$

$k=$ Weibull shape parameter

The corresponding cumulative distribution function is given by [6], [20]:

$F(V)=1-\exp \left(-(V / C)^{k}\right)$

The mean wind speed $\bar{V}$ and the standard deviation $\sigma$ of the observed data are determined using the following equations [8], [17], [20]:

$\bar{V}=C \Gamma(1+1 / k)$

Where: $\bar{V}=$ mean wind speed $[\mathrm{m} / \mathrm{s}]$

$\sigma=C\left[\Gamma(1+2 / k)-\Gamma^{2}(1+1 / k)\right]^{1 / 2}$

Where the standard gamma function is given by:

$\Gamma(x)=\int_{0}^{\infty} t^{x-1} \exp (-t) d t$

The gamma function used by J.F. Manwell et al. [12] quoting Jamil [8] is given by:

$\Gamma(x)=(\sqrt{2 \pi x})\left(x^{x-1}\right)\left(e^{-x}\right)\left(1+\frac{1}{12 x}+\frac{1}{288 x^{2}}-\frac{139}{51840 x^{3}}+\cdots\right)$

\subsection{Maximum likelihood method}

The MLE method is a mathematical expression known as a likelihood function of the wind speed data in time series format. The MLE method was used by Deligiorgi et al [9] and Costa Rocha et al [17], quoting Stevens and Smulders [20] in their study for the estimation of parameters of the Weibull wind speed distribution for wind energy utilization purposes. The MLE method is solved through numerical iterations to determine the parameters of the Weibull distribution. The shape factor $\mathrm{k}$ and the scale factor $\mathrm{c}$ are estimated by the following equations:

$k=\left[\left[\left(\sum_{i=1}^{n} V_{i}^{k} \ln V_{i}\right) /\left(\sum_{i=1}^{n} V_{i}^{k}\right)-\left(\sum_{i=1}^{n} \ln V_{i}\right) / n\right]^{-1}\right.$

$c=\left(\frac{1}{n} \sum_{i=1}^{n} V_{i}^{k}\right)^{1 / k}$

Where: $n=$ number of non-zero data values.

$i=$ measurement interval.

$V_{i}=$ wind speed measured at the interval $i[\mathrm{~m} / \mathrm{s}]$. 


\subsection{Weibull parameters extrapolation}

In a wide number of cases (Justus et al.[23]; Hennessey [24]), the Weibull seems to give a reasonable fit to observed distributions, and with Weibull $\mathrm{C}$ and $\mathrm{k}$ values known at one height, a consistent methodology can be used to adjust these parameters to another desired height. The Weibull distribution values $C_{10}$ and $k_{10}$ determined at 10 meters height $\operatorname{AGL}\left(z_{10}=10\right.$ meters $)$ are adjusted to any desired height $z$ by the relation [5]:

$C_{z}=C_{10} *\left(z / z_{10}\right)^{n}$

Where: $C_{z}=$ adjusted Weibull scale parameter to a desired height $z[\mathrm{~m} / \mathrm{s}]$.

$C_{10}=$ Weibull scale parameter at 10 meters height above ground level $[\mathrm{m} / \mathrm{s}]$.

$z_{10}=10$ meters height above ground level $[\mathrm{m}]$.

$z=$ desired height above ground level $[\mathrm{m}]$.

$k_{z}=k_{10}\left[1-0.00881 \ln \left(z_{10} / 10\right)\right] /[1-0.00881 \ln (z / 10)]$

Where: $k_{z}=$ adjusted Weibull shape parameter to a desired height $z$.

$k_{10}=$ Weibull shape parameter at 10 meters height above ground level.

Where the power law exponent $n$ is given by:

$n=\left[0.37-0.088 \ln \left(C_{10}\right)\right] /\left[1-0.088 \ln \left(z_{10} / 10\right)\right]$

\subsection{Site specific wind speeds}

There are two wind speeds that are very useful to wind energy investors and assessors. These are called the most probable $\left(V_{m p}\right)$ and maximum energy carrying $\left(V_{E m a x}\right)$ wind speeds. They are given in terms of the Weibull 2parameters as [6]:

$V_{m p}=C[(k-1) / k]^{1 / k}$

Where: $V_{m p}=$ the most probable wind speeds $[\mathrm{m} / \mathrm{s}]$.

$V_{E \max }=C[(k+2) / k]^{1 / k}$

Where: $V_{E \max }=$ the maximum energy carrying wind speeds $[\mathrm{m} / \mathrm{s}]$.

\subsection{Wind shear characterization wind speeds}

Since the observed wind speed data were measured at 10 meters height AGL and the desired anemometer level is most often at a different height, there is a need characterize the wind shear, variation of wind speed with elevation. The most commonly used methods of estimating wind shear are known as the log law and the power law [10]. Given that wind speed in general increases with elevation, and that wind turbines are designed to operate at different hub heights when compared to the available measured wind data, the observed wind speed height $\left(z_{10}=10\right.$ meters AGL) can be extrapolated to the turbine hub height through the power law expression given as [11]:

$V\left(z_{2}\right)=V\left(z_{10}\right)\left(z_{2} / z_{10}\right)^{\alpha}$

Where: $V\left(z_{2}\right)=$ wind speed at the wind turbine hub height $z_{2}[\mathrm{~m} / \mathrm{s}]$

$V\left(z_{10}\right)=$ wind speed at original height $z_{10}=10$ meters AGL $[\mathrm{m} / \mathrm{s}]$

$\alpha_{1}=$ power law exponent proposed by [12]:

$\alpha_{1}=\left[0.37-0.088 \ln \left(v_{10}\right)\right] /\left[1-0.088 \ln \left(z_{10} / 10\right)\right]$

\subsection{Wind power density estimation}

To calculate the mean power on a long time T (a month, a season, a year. ...), Tchinda et al. [2], quoting Petersen et al.[22], proposed the use of $f(\bar{V})$, the statistical distribution of the mean speed corresponding to the interval of time T. therefore wind power density is given by [2]:

$\bar{P}=(1 / 2) * \rho *\left(1+3 I^{2}\right) \int_{0}^{\infty} f(\bar{V}) \cdot \bar{V}^{3}$

Where: $\bar{P}=$ wind power density $\left[\right.$ watts $\left./ \mathrm{m}^{2}\right]$.

$f(\bar{V})=$ Statistical distribution of the mean speed $\bar{V}$.

The wind power density can be estimated from the Weibull parameters as [5], [20]:

$\bar{P}=(1 / 2) * \rho *\left(1+3 I^{2}\right) C^{3}(1+3 / k)$

Where: $I$ : turbulence factor, $I=\frac{\sigma_{v}}{\bar{V}}$;

$\sigma_{v}:$ The standard deviation of the twelve month wind speed $[\mathrm{m} / \mathrm{s}]$

$\bar{V}:$ mean wind speed $[\mathrm{m} / \mathrm{s}]$

$\rho=$ air density at the site, is often written in a simple form [4]:

$\rho=\rho_{0}-1.194 * 10^{-4} * H_{m}$

Where: $H_{m}=$ site elevation in meters

The air density value at sea level is $\rho_{0}=1.225 \mathrm{~kg} / \mathrm{m}^{3}$.

The site elevation is 242 meters, and based on the equation 18 , the air density value is $\rho=1.196 \mathrm{~kg} / \mathrm{m}^{3}$. 


\subsection{Extractable wind energy estimation}

The daily extractable wind energy is given by:

$\bar{E}_{d}=(24 / 1000) * \bar{P}$

Where: $\bar{E}_{d}=$ daily extractable wind energy $\left[\mathrm{kWh} / \mathrm{m}^{2}\right.$. day $]$.

Therefore the daily extractable wind energy can be estimated from the Weibull parameters as:

$\bar{E}_{d}=14.35 * 10^{-3} * \rho *\left(1+3 I^{2}\right) C^{3}(1+3 / k)$

The monthly extractable wind energy can be estimated from the Weibull parameters as:

$\bar{E}_{m}=14.35 * 10^{-3} * d_{j} * \rho *\left(1+3 I^{2}\right) C^{3}(1+3 / k)$

Where: $\bar{E}_{m}=$ monthly extractable wind energy $\left[\mathrm{kWh} / \mathrm{m}^{2}\right.$. month $]$.

$d_{d}=$ number of days in the month considered.

The annual extractable mean energy $\bar{E}_{a n}$ is the sum of the monthly extractable wind energies. $\bar{E}_{a n}$ Can be formulated as follows [2], [14], [18]:

$\bar{E}_{a n}=\sum_{m=1}^{n=12} \bar{E}_{m}$

Where: $\bar{E}_{a n}=$ annual extractable energy $\left[\mathrm{kWh} / \mathrm{m}^{2}\right.$. an $]$.

\subsection{Maximum extractable wind energy (Betz theory)}

The power extracted by the blades is customarily expressed as a fraction of the upstream wind power and the theoretical maximum value is given as follows [3]:

$\bar{P}_{\max }=(16 / 27) * \bar{P}=C_{p} * \bar{P}$

Where: $\bar{P}_{\max }=$ maximum extractable wind power density $\left[\mathrm{watts} / \mathrm{m}^{2}\right]$

$C_{p}=$ Rotor efficiency.

For a given upstream wind speed, the power coefficient of the rotor or the rotor efficiency $C_{p}$ has a theoretical maximum value of $16 / 27$ or 0.59 , known as the Betz limit. When considering the Betz limit and for the given site, the air mean specific mass, the maximum wind power density extracted by the blades is given by:

$\bar{P}_{\max }=(16 / 27) *(1 / 2) * \bar{P}$

Therefore the maximum power extracted is given as followed:

$\bar{P}_{\max }=0.354 *\left(1+3 I^{2}\right) C^{3}(1+3 / k)$

The maximum daily energy extracted by the blades is given by:

$\bar{E}_{\text {max }, d}=24 * 10^{-3} \cdot \bar{P}_{\max }$

Where: $\bar{E}_{\max , d}=$ maximum daily extractable wind energy $\left[\mathrm{kWh} / \mathrm{m}^{2}\right.$.day $]$

As a result:

$\bar{E}_{\text {max }, d}=8.50 * 10^{-3} *\left(1+3 I^{2}\right) C^{3}(1+3 / k)$

The maximum monthly energy extracted by the blades, estimated from the Weibull parameters is given:

$\bar{E}_{\text {max }, m}=8.50 * 10^{-3} * d_{j} *\left(1+3 I^{2}\right) C^{3}(1+3 / k)$

Where: $\bar{E}_{\text {max }, m}=$ maximum monthly extractable wind energy $\left[\mathrm{kWh} / \mathrm{m}^{2}\right.$. month $]$.

The maximum yearly energy extracted by the blades is given by:

$\bar{E}_{\text {max }, a n}=\sum_{m=1}^{n=12} \bar{E}_{\text {max }, m} \quad\left(\mathrm{kWh} / \mathrm{m}^{2} \cdot\right.$ year $)$

Where: $\bar{E}_{\text {max }, a n}=$ maximum yearly extractable wind energy $\left[\mathrm{kWh} / \mathrm{m}^{2}\right.$. year $]$.

\section{Results and discussions}

In this study, wind speed data analyses were done using Microsoft Excel ${ }^{\circledR}$. The dimensionless Weibull shape parameter $\mathrm{k}$ and the Weibull scale parameter $\mathrm{C}$ were estimated using the MLE method. In addition, Weibull mean wind speed $\overline{\boldsymbol{V}}$, standard deviation, most probable $\left(V_{m p}\right)$, maximum energy carrying $\left(V_{E m a x}\right)$ wind speeds and power density are summarized in table 2 .

It can be seen from the table 2 that the highest monthly wind speeds occur in March $(2.11 \mathrm{~m} / \mathrm{s})$, April $(2.71 \mathrm{~m} / \mathrm{s})$, May $(2.52 \mathrm{~m} / \mathrm{s})$, June $(2.34 \mathrm{~m} / \mathrm{s})$ and July $(2.34 \mathrm{~m} / \mathrm{s})$ while the minimum monthly wind speeds occur in November $(1.40 \mathrm{~m} / \mathrm{s})$ and December $(1.24 \mathrm{~m} / \mathrm{s})$. The overall yearly mean wind speed in Garoua is found to be $1.91 \mathrm{~m} / \mathrm{s}$. Moreover, the knowledge of the most probable $\left(V_{m p}\right)$ and maximum energy carrying $\left(V_{E m a x}\right)$ wind speeds help to establish whether or not this particular location is suitable for wind turbine. The results of the most probable $\left(V_{m p}\right)$ and maximum energy carrying $\left(V_{E \max }\right)$ wind speeds analyses are presented in the table 2. It showed that the values of $V_{m p}$ and $V_{\text {Emax }}$ from January to December range from 1.22 to $2.81 \mathrm{~m} / \mathrm{s}$ and 1.63 to $3.21 \mathrm{~m} / \mathrm{s}$ respectively. The Weibull shape and scale parameters ( $k$ and $\mathrm{C}$ ) show that $\mathrm{k}$ varies from 2.76 (October) to 6.40 (March), while $C$ is between 1.39 (December) and $2.97 \mathrm{~m} / \mathrm{s}$ (April). In addition, it can be observed that the power density range from $3.15 \mathrm{~W} / \mathrm{m}^{2}$ in December to $25.83 \mathrm{~W} / \mathrm{m}^{2}$ in March. Therefore, this location falls under wind energy class $1\left(<100 \mathrm{~W} / \mathrm{m}^{2}\right)$ [12], 
adequate for mechanical applications such as small scale water pumping. The tables 12 and 13 summarize the maximum extractable daily and monthly wind energy.

Table 2: Some of the results of Weibull Analysis

\begin{tabular}{llllllll}
\hline Month & $\begin{array}{l}V_{\text {weibull }} \\
(\mathrm{m} / \mathrm{s})\end{array}$ & $\begin{array}{l}\sigma_{\text {weibull }} \\
(\mathrm{m} / \mathrm{s})\end{array}$ & $\begin{array}{l}C_{\text {weibull }} \\
(\mathrm{m} / \mathrm{s})\end{array}$ & $k_{\text {weibull }}$ & $\begin{array}{l}V_{m p} \\
(\mathrm{~m} / \mathrm{s})\end{array}$ & $\begin{array}{l}V_{\text {Emax }} \\
(\mathrm{m} / \mathrm{s})\end{array}$ & $\begin{array}{l}p(\mathrm{v}) \\
\left(\mathrm{W} / \mathrm{m}^{2}\right)\end{array}$ \\
\hline Jan. & 1.59 & 0.51 & 1.77 & 3.47 & 1.60 & 2.02 & 6.18 \\
Feb. & 1.59 & 0.54 & 1.78 & 3.26 & 1.59 & 2.06 & 6.46 \\
Mar. & 2.11 & 0.38 & 2.26 & 6.40 & 2.20 & 2.36 & 10.19 \\
Apr. & 2.71 & 0.67 & 2.97 & 4.60 & 2.81 & 3.21 & 25.83 \\
May & 2.52 & 0.56 & 2.73 & 5.16 & 2.62 & 2.91 & 19.34 \\
June & 2.49 & 0.65 & 2.74 & 4.31 & 2.58 & 2.99 & 20.81 \\
July & 2.34 & 0.73 & 2.60 & 3.58 & 2.37 & 2.94 & 19.26 \\
Aug. & 1.84 & 0.58 & 2.05 & 3.50 & 1.86 & 2.33 & 9.54 \\
Sep. & 1.60 & 0.50 & 1.78 & 3.59 & 1.62 & 2.01 & 6.18 \\
Oct. & 1.59 & 0.59 & 1.78 & 2.93 & 1.54 & 2.12 & 6.81 \\
Nov. & 1.40 & 0.55 & 1.57 & 2.76 & 1.34 & 1.92 & 4.85 \\
Dec. & 1.24 & 0.44 & 1.39 & 3.08 & 1.22 & 1.63 & 3.15 \\
\hline
\end{tabular}

The figure 1 illustrates monthly frequencies distribution of wind speed. The plots were drawn using the values of scale and shape parameters obtained with equations (3) and (4). The corresponding monthly cumulative frequencies distributions are shown in figures 2.

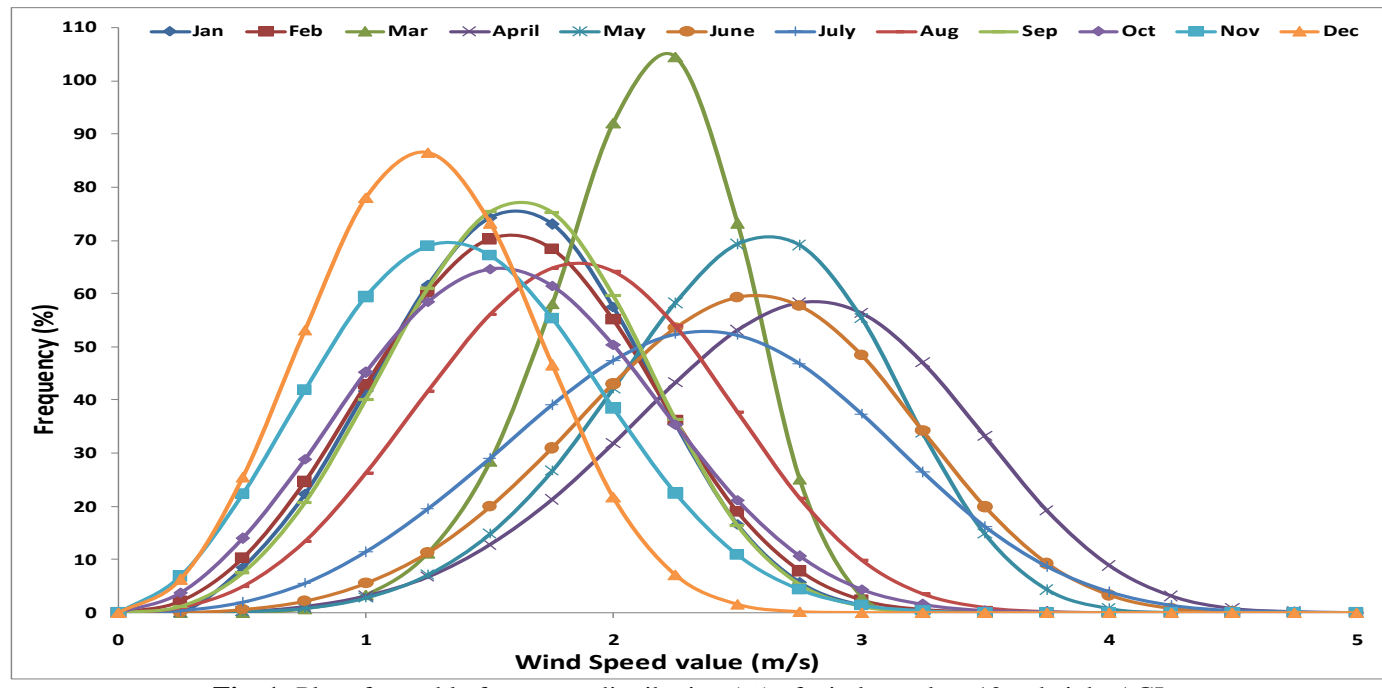

Fig. 1: Plot of monthly frequency distribution (\%) of wind speed, at $10 \mathrm{~m}$ height AGL.

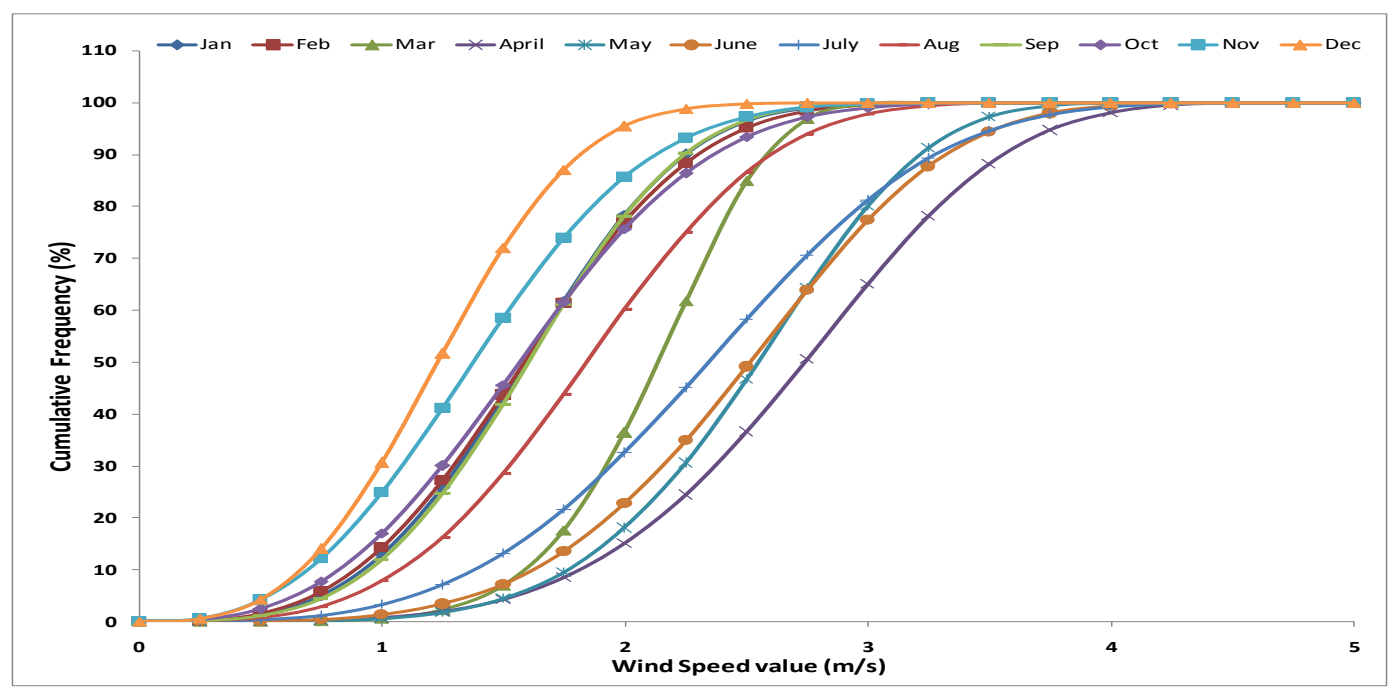

Fig. 2: Plot of monthly cumulative frequency distribution (\%) of wind speed, at $10 \mathrm{~m}$ height AGL 


\subsection{Application to water pumping}

The average hydraulic power output $\bar{P}_{h y d}$ of a wind pump (at sea level) is given by [19]:

$\bar{P}_{\text {hyd }}=B * \bar{V}^{3} * A_{\text {rotor }}$

Where: $\bar{V}=$ average wind speed at the site $[\mathrm{m} / \mathrm{s}]$

$A_{\text {rotor }}=$ swept rotor area $\left[\mathrm{m}^{2}\right]$.

$B=$ quality factor expressing the effectiveness with which wind power is converted to net hydraulic power. Normal values of $B$ range from 0.05 to 0.15 , the first being acceptable, the second value being excellent. The value $B=0.1$ can be regarded as an average value for a well-designed wind pump. Therefore the useful average hydraulic power output $\bar{P}_{\text {hyd }}$ can be estimated is given by [24]:

$\bar{P}_{\text {hyd }}=0.1 * \bar{V}^{3} * A_{\text {rotor }}$

Where $\bar{P}_{\text {hyd }}$ is a function of the pump head, the required water flow rate, the density of water, and the acceleration due to gravity. Otherwise, the hydraulic power output is given:

$\bar{P}_{h y d}=\rho_{w} q g H$

Where: $\bar{P}_{\text {hyd }}=$ average hydraulic power output $\left[\mathrm{w} / \mathrm{m}^{2}\right]$.

$\rho_{w}=$ density of water $\left[\mathrm{kg} / \mathrm{m}^{3}\right]$

$q=$ average water flow rate $\left[\mathrm{m}^{3} /\right.$ day $]$.

$g=$ acceleration of gravity $\left[\mathrm{m}^{2} / \mathrm{s}\right]$.

$H=$ total pumping head $[m]$.

To estimate the daily water production of the hypothetic windmill based on the total dynamic head, for small scale water pumping applications, the table 3 [19] has been used as a guideline. Weibull parameters $C_{10}$ and $k_{10}$ determined at 10 meters height AGL, were extrapolated to 15 and 20 meters AGL (Table 7 and 8) in order to evaluate the wind shear (table 9$)$, then to estimate the most probable $\left(V_{m p}\right)$ and maximum energy carrying $\left(V_{E m a x}\right)$ wind speeds (Table 10 and 11).

For community water supply in the north region, a total pump head of 30 meters has been utilized for a windmill that is 20 meters height AGL. The Weibull distribution parameters determined at 10 meters height AGL were extrapolated to 20 meters height AGL using the equations (9) and (10). The results are presented in the table 4. On average, a hypothetic windmill with 2.5 to 5 meters blade's diameter could produce less that than $20 \mathrm{~m}^{3} /$ day. For a rotor diameter above 5 meters, the daily water production could be sufficient for a community of 500 persons approximately.

Table 3: Rough indication of water depths, required daily volume of water and typical size of the rotor for various applications [19].

\begin{tabular}{|c|c|c|c|c|c|c|}
\hline Application & $\begin{array}{l}\text { Head } \\
\text { very } \\
\text { low } \\
<3 \mathrm{~m}\end{array}$ & $\begin{array}{l}\text { low } \\
3-10 m\end{array}$ & $\begin{array}{l}\text { medium } \\
10-30 m\end{array}$ & $\begin{array}{l}\text { deep } \\
>30 m\end{array}$ & Daily volume $\left(m^{3} / d a y\right)$ & $\begin{array}{l}\text { Typical rotor } \\
\text { diameter }(m)\end{array}$ \\
\hline $\begin{array}{l}\text { Community water } \\
\text { supply }\end{array}$ & & & $*$ & * & 20 (500 persons) & 2.5 to 7.0 \\
\hline Domestic water supply & & & $*$ & $*$ & 1 - 3 (small farm) & 1.5 to 2.5 \\
\hline Cattle watering & & & $*$ & $*$ & 20 (500 head $)$ & 1.5 to 4.5 \\
\hline Irrigation & $*$ & $*$ & & & $40-100(\approx 1$ hectare $)$ & 2.5 to 5.5 \\
\hline Drainage & $*$ & & & & 100 & 2.5 to 3.5 \\
\hline
\end{tabular}

Table 4: Daily flow rate $\left(\mathrm{m}^{3} /\right.$ day) based on the blade diameter at $20 \mathrm{~m}$ Height AGL

\begin{tabular}{lllllllllll}
\hline Typical rotor diameter $(\mathrm{m})$ & 2.50 & 3.00 & 3.50 & 4.00 & 4.50 & 5.00 & 5.50 & 6.00 & 6.50 & 7.00 \\
\hline Jan. & 2.82 & 4.06 & 5.52 & 7.21 & 9.13 & 11.27 & 13.64 & 16.23 & 19.05 & 22.09 \\
Feb. & 2.94 & 4.24 & 5.76 & 7.53 & 9.53 & 11.76 & 14.23 & 16.94 & 19.88 & 23.06 \\
Mar. & 2.94 & 4.24 & 5.76 & 7.53 & 9.53 & 11.76 & 14.23 & 16.94 & 19.88 & 23.06 \\
Apr. & 10.75 & 15.49 & 21.08 & 27.53 & 34.84 & 43.02 & 52.05 & 61.94 & 72.70 & 84.31 \\
May & 8.15 & 11.74 & 15.98 & 20.87 & 26.42 & 32.61 & 39.46 & 46.96 & 55.12 & 63.92 \\
June & 8.80 & 12.68 & 17.25 & 22.54 & 28.52 & 35.21 & 42.61 & 50.71 & 59.51 & 69.02 \\
July & 8.21 & 11.82 & 16.09 & 21.01 & 26.60 & 32.83 & 39.73 & 47.28 & 55.49 & 64.36 \\
Aug. & 4.21 & 6.07 & 8.26 & 10.78 & 13.65 & 16.85 & 20.39 & 24.26 & 28.48 & 33.03 \\
Sep. & 2.82 & 4.06 & 5.52 & 7.21 & 9.12 & 11.26 & 13.63 & 16.22 & 19.04 & 22.08 \\
Oct. & 3.09 & 4.46 & 6.06 & 7.92 & 10.02 & 12.38 & 14.98 & 17.82 & 20.92 & 24.26 \\
Nov. & 2.26 & 3.26 & 4.43 & 5.79 & 7.33 & 9.04 & 10.94 & 13.02 & 15.28 & 17.73 \\
Dec. & 1.50 & 2.17 & 2.95 & 3.85 & 4.88 & 6.02 & 7.28 & 8.67 & 10.17 & 11.80 \\
Average & 4.88 & 7.02 & 9.56 & 12.48 & 15.80 & 19.50 & 23.60 & 28.08 & 32.96 & 38.23 \\
\hline
\end{tabular}


For domestic water supply in the north region, a total pump head of 15 meters has been utilized for a hypothetic windmill that is 20 meters height AGL. On average, a hypothetic windmill with 1.5 to 2.5 meters blade's diameter could produce between 3.51 and $9.75 \mathrm{~m}^{3} /$ day. The results are presented in the table 5 .

For cattle watering, a total pump head of 15 meters has been utilized. On average, a hypothetic windmill with 1.5 to 4.5 meters blade's diameter could produce from 3.51 to $31.59 \mathrm{~m}^{3} /$ day. The results are as well presented in the table 5 .

Table 5: Daily flow rate $\left(\mathrm{m}^{3} / \mathrm{day}\right)$ based on the blade diameter at $15 \mathrm{~m}$ Height AGL

\begin{tabular}{llllllll}
\hline Typical rotor diameter $(\mathrm{m})$ & 1.5 & 2 & 2.5 & 3.00 & 3.50 & 4.00 & 4.50 \\
\hline Jan. & 2.03 & 3.61 & 5.64 & 8.12 & 11.05 & 14.43 & 18.26 \\
Feb. & 2.12 & 3.76 & 5.88 & 8.47 & 11.53 & 15.06 & 19.06 \\
Mar. & 2.12 & 3.76 & 5.88 & 8.47 & 11.53 & 15.06 & 19.06 \\
Apr. & 7.74 & 13.77 & 21.51 & 30.97 & 42.16 & 55.06 & 69.69 \\
May & 5.87 & 10.44 & 16.31 & 23.48 & 31.96 & 41.75 & 52.83 \\
June & 6.34 & 11.27 & 17.61 & 25.35 & 34.51 & 45.07 & 57.04 \\
July & 5.91 & 10.51 & 16.42 & 23.64 & 32.18 & 42.03 & 53.19 \\
Aug. & 3.03 & 5.39 & 8.42 & 12.13 & 16.51 & 21.57 & 27.30 \\
Sep. & 2.03 & 3.60 & 5.63 & 8.11 & 11.04 & 14.42 & 18.25 \\
Oct. & 2.23 & 3.96 & 6.19 & 8.91 & 12.13 & 15.84 & 20.05 \\
Nov. & 1.63 & 2.89 & 4.52 & 6.51 & 8.86 & 11.58 & 14.65 \\
Dec. & 1.08 & 1.93 & 3.01 & 4.33 & 5.90 & 7.70 & 9.75 \\
Average & 3.51 & 6.24 & 9.75 & 14.04 & 19.11 & 24.96 & 31.59 \\
\hline
\end{tabular}

For farm irrigation, a total pump head of 10 meters has been utilized for a windmill that is 20 meters height AGL. The results are presented in the table 6 . On average, it could be attractive to choose a hypothetic windmill with blade's diameter of more than 4 meters to produce more than $40 \mathrm{~m}^{3} /$ day. For rotor diameter of 5.5 meters, the windmill will produce more than 40 $\mathrm{m}^{3} /$ day from January to October. Additionally, the windmill could produce a maximum of $156 \mathrm{~m}^{3} /$ day in April, more than $100 \mathrm{~m}^{3} /$ day from April to July which correspond to the dry season when the need is in rise.

Table 6: Daily flow rate $\left(\mathrm{m}^{3} / \mathrm{day}\right)$ based on the blade diameter at $10 \mathrm{~m}$ Height AGL

\begin{tabular}{lllllllllll}
\hline Rotor diameter $(\mathrm{m})$ & 2.50 & 3.00 & 3.50 & 4.00 & 4.50 & 5.00 & 5.50 & 6.00 & 6.50 & 7.00 \\
\hline Jan. & 8.45 & 12.17 & 16.57 & 21.64 & 27.39 & 33.81 & 40.92 & 48.69 & 57.15 & 66.28 \\
Feb. & 8.82 & 12.71 & 17.29 & 22.59 & 28.59 & 35.29 & 42.70 & 50.82 & 59.64 & 69.17 \\
Mar. & 8.82 & 12.71 & 17.29 & 22.59 & 28.59 & 35.29 & 42.70 & 50.82 & 59.64 & 69.17 \\
Apr. & 32.26 & 46.46 & 63.24 & 82.59 & 104.53 & 129.05 & 156.15 & 185.83 & 218.10 & 252.94 \\
May & 24.46 & 35.22 & 47.94 & 62.62 & 79.25 & 97.84 & 118.39 & 140.89 & 165.35 & 191.77 \\
June & 26.41 & 38.03 & 51.76 & 67.61 & 85.57 & 105.64 & 127.82 & 152.12 & 178.52 & 207.05 \\
July & 24.63 & 35.46 & 48.27 & 63.04 & 79.79 & 98.50 & 119.19 & 141.84 & 166.47 & 193.07 \\
Aug. & 12.64 & 18.20 & 24.77 & 32.35 & 40.95 & 50.55 & 61.16 & 72.79 & 85.43 & 99.08 \\
Sep. & 8.45 & 12.17 & 16.56 & 21.63 & 27.37 & 33.79 & 40.89 & 48.66 & 57.11 & 66.23 \\
Oct. & 9.28 & 13.37 & 18.19 & 23.76 & 30.07 & 37.13 & 44.93 & 53.46 & 62.75 & 72.77 \\
Nov. & 6.78 & 9.77 & 13.29 & 17.36 & 21.98 & 27.13 & 32.83 & 39.07 & 45.85 & 53.18 \\
Dec. & 4.51 & 6.50 & 8.85 & 11.56 & 14.63 & 18.06 & 21.85 & 26.00 & 30.52 & 35.39 \\
Average & 14.63 & 21.06 & 28.67 & 37.44 & 47.39 & 58.51 & 70.79 & 84.25 & 98.88 & 114.68 \\
\hline
\end{tabular}

Table 7: Weibull scale parameter $C$ extrapolation to 15 and $20 \mathrm{~m}$ AGL

\begin{tabular}{lllllllllllll}
\hline Month & Jan. & Feb. & Mar. & Apr. & May & June & July & Aug. & Sept. & Oct. & Nov. & Dec. \\
\hline 10 m HAGL & 1.77 & 1.78 & 2.26 & 2.97 & 2.73 & 2.74 & 2.60 & 2.05 & 1.78 & 1.78 & 1.57 & 1.39 \\
15 m HAGL & 2.01 & 2.02 & 2.55 & 3.32 & 3.07 & 3.07 & 2.92 & 2.32 & 2.02 & 2.02 & 1.80 & 1.59 \\
20 m HAGL & 2.21 & 2.22 & 2.78 & 3.59 & 3.32 & 3.33 & 3.17 & 2.53 & 2.22 & 2.22 & 1.98 & 1.76 \\
\hline
\end{tabular}

Table 8: Weibull shape parameter extrapolation to 15 and $20 \mathrm{~m}$ AGL

\begin{tabular}{|c|c|c|c|c|c|c|c|c|c|c|c|c|}
\hline Month & Jan. & Feb. & Mar. & Apr. & May & June & July & Aug. & Sept. & Oct. & Nov. & Dec. \\
\hline $10 \mathrm{~m} \mathrm{HAGL}$ & 3.47 & 3.26 & 6.40 & 4.60 & 5.16 & 4.31 & 3.58 & 3.50 & 3.59 & 2.93 & 2.76 & 3.08 \\
\hline $15 \mathrm{~m} \mathrm{HAGL}$ & 3.60 & 3.38 & 6.64 & 4.77 & 5.35 & 4.47 & 3.71 & 3.63 & 3.72 & 3.04 & 2.86 & 3.19 \\
\hline $20 \mathrm{~m} \mathrm{HAGL}$ & 3.70 & 3.47 & 6.82 & 4.90 & 5.50 & 4.59 & 3.81 & 3.73 & 3.82 & 3.12 & 2.94 & 3.28 \\
\hline
\end{tabular}

Table 9: Mean wind speed extrapolation to 15 and 20 meters AGL

\begin{tabular}{|c|c|c|c|c|c|c|c|c|c|c|c|c|}
\hline Month & Jan. & Feb. & Mar. & Apr. & May & June & July & Aug. & Sept. & Oct. & Nov. & Dec. \\
\hline $10 \mathrm{~m} \mathrm{HAGL}$ & 1.59 & 1.59 & 2.09 & 2.71 & 2.51 & 2.49 & 2.33 & 1.84 & 1.60 & 1.58 & 1.40 & 1.24 \\
\hline $15 \mathrm{~m} \mathrm{HAGL}$ & 1.81 & 1.82 & 2.37 & 3.04 & 2.82 & 2.80 & 2.63 & 2.09 & 1.83 & 1.81 & 1.60 & 1.43 \\
\hline $20 \mathrm{~m} \mathrm{HAGL}$ & 1.99 & 2.00 & 2.59 & 3.30 & 3.07 & 3.05 & 2.86 & 2.29 & 2.01 & 1.99 & 1.77 & 1.58 \\
\hline
\end{tabular}


Table 10: Most probable wind speed extrapolation to 15 and $20 \mathrm{~m}$ AGL

\begin{tabular}{lllllllllllll}
\hline Month & Jan. & Feb. & Mar. & Apr. & May & June & July & Aug. & Sept. & Oct. & Nov. & Dec. \\
\hline 10 m HAGL & 1.60 & 1.59 & 2.20 & 2.81 & 2.62 & 2.58 & 2.37 & 1.86 & 1.62 & 1.54 & 1.34 & 1.22 \\
15 m HAGL & 1.84 & 1.82 & 2.49 & 3.16 & 2.95 & 2.90 & 2.68 & 2.12 & 1.86 & 1.77 & 1.55 & 1.42 \\
20 m HAGL & 2.03 & 2.01 & 2.72 & 3.43 & 3.20 & 3.15 & 2.92 & 2.33 & 2.05 & 1.96 & 1.72 & 1.57 \\
\hline
\end{tabular}

Table 11: Maximum energy carrying wind speeds $\left(V_{\text {Emax }}\right)$ extrapolation to 15 and $20 \mathrm{~m}$ AGL

\begin{tabular}{lllllllllllll}
\hline Month & Jan. & Feb. & Mar. & Apr. & May & June & July & Aug. & Sept. & Oct. & Nov. & Dec. \\
\hline 10 m HAGL & 2.02 & 2.06 & 2.36 & 3.21 & 2.91 & 2.99 & 2.94 & 2.33 & 2.01 & 2.12 & 1.92 & 1.63 \\
15 m HAGL & 2.28 & 2.32 & 2.66 & 3.57 & 3.25 & 3.33 & 3.28 & 2.62 & 2.27 & 2.39 & 2.16 & 1.85 \\
20 m HAGL & 2.48 & 2.53 & 2.89 & 3.85 & 3.52 & 3.60 & 3.54 & 2.84 & 2.48 & 2.60 & 2.36 & 2.03 \\
\hline
\end{tabular}

Table 12: Extractable daily, monthly wind energy

\begin{tabular}{lccc}
\hline Period & $\bar{P}\left(w / m^{2}\right)$ & $\bar{E}_{d}\left(k W h / m^{2}\right.$. day $)$ & $\bar{E}_{m}\left(\mathrm{kWh} / \mathrm{m}^{2} . m o n t h\right)$ \\
\hline Jan. & 8.06 & 0.19 & 5.99 \\
Feb. & 8.67 & 0.21 & 5.82 \\
Mar. & 11.21 & 0.27 & 8.34 \\
Apr. & 30.57 & 0.73 & 22.01 \\
May & 22.21 & 0.53 & 16.52 \\
June & 25.09 & 0.60 & 18.06 \\
July & 24.82 & 0.60 & 18.46 \\
Aug. & 12.39 & 0.30 & 9.22 \\
Sep. & 7.96 & 0.19 & 5.73 \\
Oct. & 9.62 & 0.23 & 7.16 \\
Nov. & 7.08 & 0.17 & 5.10 \\
Dec. & 4.34 & 0.10 & 3.23 \\
\hline
\end{tabular}

Table 13: Maximum Extractable daily, monthly and yearly wind energy

\begin{tabular}{|c|c|c|c|}
\hline Period & $\bar{P}_{\max }\left(w / m^{2}\right)$ & $\bar{E}_{\max . d}\left(k W h / m^{2} \cdot d a y\right)$ & $\bar{E}_{\text {max.m }}\left(\mathrm{kWh} / \mathrm{m}^{2}\right.$. month $)$ \\
\hline Jan. & 4.77 & 0.11 & 3.55 \\
\hline Feb. & 5.14 & 0.12 & 3.45 \\
\hline Mar. & 6.64 & 0.16 & 4.94 \\
\hline Apr. & 18.11 & 0.43 & 13.04 \\
\hline May & 13.16 & 0.32 & 9.79 \\
\hline June & 14.87 & 0.36 & 10.70 \\
\hline July & 14.71 & 0.35 & 10.94 \\
\hline Aug. & 7.34 & 0.18 & 5.46 \\
\hline Sep. & 4.72 & 0.11 & 3.40 \\
\hline Oct. & 5.70 & 0.14 & 4.24 \\
\hline Nov. & 4.20 & 0.10 & 3.02 \\
\hline Dec. & 2.57 & 0.06 & 1.91 \\
\hline
\end{tabular}

\section{Conclusion}

The main goal of this study was to assess the wind energy for small scale water pumping in the north region of Cameroon. The following observation can be done throughout this study:

- Weibull distribution proved to be a useful tool to predict the wind regime relevant to wind power generating systems.

- Wind energy potential in the north region of Cameroon is not fitted for generating electricity. Furthermore, based on the foreseen applications, the following could be concluded.

- For community water supply, a hypothetic windmill with a rotor diameter bigger than 5 meters could produce on average more than $20 \mathrm{~m}^{3} /$ day, given total pump head of 30 meters.

- For domestic water supply, a hypothetic windmill with a rotor diameter of 1.5 meters could produce $3.51 \mathrm{~m}^{3} /$ day while a rotor diameter of 2.5 meters could produce $9.75 \mathrm{~m}^{3} /$ day on average, given a total pump head of 15 meters.

- For cattle watering, a hypothetic windmill with a rotor diameter of 4.5 meters could produce $3.51 \mathrm{~m}^{3} /$ day while a rotor diameter of 4.5 meters could produce $31.59 \mathrm{~m}^{3} /$ day on average, given a total pump head of 15 meters.

- For farm irrigation, a hypothetic windmill with a rotor diameter of 5.5 meters could produce on average, more than $40 \mathrm{~m}^{3} /$ day from January to October, given a total pump head of 10 meters. 
Although the results of this study encourages the utilization of water pumping windmills in rural areas to help easing difficulties accessing to clean water for household use, small scale irrigation, and livestock, further wind characterization studies at different height above ground level are required.

\section{References}

[1] Abdeen Mustafa Omer. "Wind mechanical engineering: energy for water pumping in rural areas in sudan", Technical Proceedings of the 2011 Clean Technology Conference and Trade Show.

[2] Réné Tchinda, Ernest Kaptouom. "Wind energy in Adamaoua and North Cameroon provinces", Energy Conversion and Management 44 (2003) 845-857.

[3] D.A. Fadare. "A Statistical Analysis of Wind Energy Potential in Ibadan, Nigeria, Based on Weibull Distribution Function", The Pacific Journal of Science and Technology Volume 9. Number 1. May-June 2008, Springer.

[4] Mukund R. Patel. Wind and Solar Power Systems, U.S. Merchant Marine Academy Kings Point, New York.

[5] C.G. Justus, W.R. Hargraves, Amir mikail and denise grabber. "Methods for estimating speed frequency distributions", Journal of applied meteorology, volume 17, November 1977.

[6] Ajayi, O., Fagbenle, R., Katende. "Wind Profile Characteristics and Econometrics Analysis of Wind Power Generation of a Site in Sokoto State, Nigeria", Energy science and technology vol. 1, N² 2, 2011 pp. 54-66.

[7] Salahaddin A. Ahmed. "Comparative study of four methods for estimating Weibull parameters for Halabja, Iraq", International Journal of Physical Sciences Vol. 8(5), pp. 186-192, 9 February, 2013.

[8] Jamil, M. "Wind Power Statistics and Evaluation of Wind Energy Density", Wind Engineering, 18, NOS, $227-240,1994$.

[9] D. Deligiorgi, D. Kolokotsa, T. Papakostas, E. Mantou. "Analysis of the Wind Field at the Broader Area of Chania, Crete" Proc. of the 3rd IASME/WSEAS Int. Conf. on Energy, Environment, Ecosystems and Sustainable Development, Agios Nikolaos, Greece, July 24-26, 2007.

[10] M.L. Ray, A.L. Rogers, and J.G. McGowan. "Analysis of wind shear models and trends in different terrains", Renewable Energy Research Laboratory, Department of Mechanical \& Industrial Engineering, University of Massachusetts, Amherst MA 01003.

[11] Olayinka S Ohunakin1, Olanrewaju M Oyewola and Muyiwa S Adaramola. "Economic analysis of wind energy conversion systems using levelized cost of electricity and present value cost methods in Nigeria", International Journal of Energy and Environmental Engineering, 2013 $4: 2$.

[12] J.F. Manwell, J.G. McGowan and A.L. Rogers. "Wind energy explained: Theory, design and application”, John Wiley and Sons Ltd. 2002.

[13] B. Ozerdem, H.M. Turkeli. "Wind energy potential estimation and micrositting on Izmir Institute of Technology Campus, Turkey", Renewable Energy 30 (2005) 1623-1633.

[14] Réné Tchinda, Joseph Kendjioa, Ernest Kaptouom, Donatien Njomo. "Estimation of mean wind energy available in far north Cameroon", Energy Conversion \& Management 41 (2000) 1917 \pm 1929.

[15] W. palz, W. schnell. Solar Energy R\&D in the European Community. "Series G Wind Energy Volume 1", Proceedings of the EC Contractors' Meeting held in Brussels, 23-24 November 1982.

[16] Mark L. Morrissey, werner E. cook, J. Scott greene. "An Improved Method for Estimating the Wind Power Density Distribution Function”, Journal of atmospheric and oceanic technology, volume 27, July 2010.

[17] P. A. Costa Rocha, R. Coelho de Sousa, C. Freitas de Andrade, M. Vieira da Silva. "Comparison of seven numerical methods for determining Weibull parameters for wind energy generation in the northeast region of Brazil", Applied Energy 89 (2012) 395-400.

[18] Clarence SEMASSOU. “Aide à la décision pour le choix de sites et systèmes énergétiques adaptés aux besoins du bénin", PhD Thesis, Ecole Doctorale de l'Université Bordeaux 1 ED 209, Nº d'ordre : 4450, 15 décembre 2011.

[19] P.T. Smulders. "Wind water pumping: the forgotten option", Energy for Sustainable Development, Volume II No. 51 January 1996.

[20] M.J. Stevens and P.T. Smulders., "The estimation of parameters of the Weibull wind speed distribution for wind energy utilization purposes", Wind Eng. 3 (2), 132-145, 1979.

[21] Cossi NA. "Estimation of the mean wind energy in Benin (Ex Dahomey)", Renew Energy 1991;1(5/6):845-53.

[22] Petersen EL et al. "Wind atlas for Denmark" Ris /-R-428, 1985. p. 229.

[23] C.G. Justus, W.R. Hargraves, and Ali Yalcin. "Nationwide assessment of potential output from wind-powered generators", Journal of applied meteorology, volume 5, $\mathrm{N}^{\circ} 7$ July 1976.

[24] Joop van Meel and Paul Smulders. Wind pumping, a Handbook, World Bank Technical Paper No. 101 (Industry and Engineering Series), Washington D.C, July 1989. 